\title{
Crying patients in General/Family Practice: incidence, reasons for encounter and health problems
}

\author{
Pacientes que Iloran en Medicina General/de Familia: \\ incidencia, razones de consulta y problemas de salud \\ Pacientes que choram em Medicina Geral/de Família: \\ incidência, razões de consulta e problemas de saúde \\ Juan Gérvas ${ }^{1 *}$, Raimundo Pastor-Sánchez ${ }^{2}$, Mercedes Pérez-Fernández ${ }^{3}$
}

\section{Keywords: \\ Crying \\ Primary Care \\ General Practice \\ Family Medicine \\ Doctor-patient Relationship}

Palabras clave:

Llorar

Atención Primaria

Medicina General

Medicina de Familia Relación Médico-paciente

\section{Abstract}

Context: Despite evidence demonstrating the benefits of understanding patients, there is a paucity of information about how physicians address psychological and social concerns of patients. No one study has been published about the incidence of crying in General/Family Practice. Objective: To know the incidence of crying in primary care/general practice, and the patients' characteristics, their reasons for encounter and their health problems. Design: A descriptive, prospective study, of one year, of three general practitioners/family physicians in Madrid, Spain. Setting: primary care (doctors' office and patients' home). Subjects: Face to face encounters with crying patients. Main outcome measure: At least one rolling tear. Results: Patients cried in 157 encounters out of a total of 18,627 giving an incidence rate of 8.4 per thousand. More frequent reasons for encounters were: feeling depressed (12.7\%), social handicap (mainly social isolation/ living alone) (6.4\%), relationship problem with partner (5.1\%) and feeling anxious (3.2\%). More frequent health problems were: depressive disorder (23.6\%), anxiety disorder (8.3\%), cerebrovascular disease (5.1\%) and loss/death of partner (3.8\%). Conclusions: Crying in primary care is not uncommon. Reasons for crying cover the whole range of human problems, mainly social and psychological problems.

\section{Resumen}

Contexto: A pesar de los estudios que demuestran los beneficios de comprender al paciente, hay escasa información sobre cómo los médicos responden a los problemas psicológicos y sociales. No hemos encontrado ningún trabajo publicado sobre la incidencia de pacientes que lloran. Objetivo: Conocer la incidencia del Ilanto en Medicina General/de Familia y las características de los pacientes, las razones de sus consultas y sus problemas de salud. Diseño: Estudio descriptivo, prospectivo, de un año de duración, realizado por tres especialistas de Medicina General/de Familia, en Madrid, España. Lugar: Atención Primaria (consultas médicas realizadas en consultorios y consultas domiciliarias). Pacientes: Encuentros "cara a cara" con pacientes que lloran. Parámetro principal: Al menos una lágrima derramada. Resultado: Lloraron pacientes en 157 encuentros de un total de 18.627, lo que resulta en una incidencia de 8,4 por mil. Las razones de consulta más frecuentes fueron: sentimiento depresivo (12,7\%), limitaciones sociales (fundamentalmente, aislamiento/vivir solo) (6,4\%), problemas de pareja $(5,1 \%)$ y sentimiento de ansiedad $(3,2 \%)$. Los problemas de salud más frecuentes fueron: depresión $(23,6 \%)$, ansiedad (8,3\%), enfermedad cerebrovascular (5,1\%) y pérdida/muerte de la pareja (3,8\%). Conclusiones: Llorar no es raro en la atención primaria. Las razones para llorar cubren el amplio campo de los problemas humanos, principalmente problemas sociales y psicológicos.

\footnotetext{
${ }^{1}$ General practitioner. Equipo CESCA. General practitioner. Spanish National Health System. jgervasc@meditex.es

${ }^{2}$ General practitioner. Equipo CESCA. General practitioner. Spanish National Health System. rpastors@meditex.es

${ }^{3}$ General practitioner. Equipo CESCA. General practitioner. Spanish National Health System. mpf1945@gmail.com

*Autor correspondente.

Fonte de financiamento: nenhuma.

Conflito de interesses: declaram não haver.

Recebido em: 16/09/2012

Aprovado em: 27/10/2012
} 


\begin{abstract}
Palavras-chave: Resumo
Chorar

Atenção Básica

Medicina Geral

Medicina de Família

Relação Médico-paciente
\end{abstract}

\section{Introduction}

General practitioners see patients as persons in the context of their ongoing life stories. All facet of life - physical, psychological, sexual, emotional, social, labour - influence the problems patients bring to their general practitioners ${ }^{1}$. Primary health care problems encompass all known human problems. Sometimes we try to avoid strong feelings - angers, fear, sadness, loss, being stuck in an unresolvable dilemma, grief - fearing that if we acknowledge them patients will pour out their hearts to us, overwhelming us and using up too much time. In interpersonal relationships, as patientphysician one, we become participant observers and some doctors are reluctant to enter into the feeling world of patients, because is too threatening. Physicians report distress and lack of therapeutic tools to deal with an angry patient, a tearful patient, a frightened patient, or one who seems unable to make a pressing decision. But those strong feelings will keep coming up in the interview if we do not do something therapeutic about them. The result will be a patient who feels isolated and misunderstood and much more time lost. It is not easy to cope with difficult situations but general practitioners have frequents troublesome patient encounters. A route out of this difficulty is a specific interaction skill called an empathic action ${ }^{2}$. Understanding patients' feelings involves the qualities of pity, sympathy and empathy ${ }^{3}$.

People cry in hospitals and psychiatric offices ${ }^{4-11}$ and primary care settings ${ }^{12,13}$ but we do not know the frequency of encounters with tearful patients and the reasons why people cry in General/Family Practice. The aim of this study was to know the incidence of crying in general practice and the patients' characteristics, their reasons for encounter and their medical problems.

\section{Subjects and methods}

The study took place in three different health centres, where the authors work, in Madrid, Spain. Spanish general practitioners are public employees, paid by salary, have a patient list (of around 2,000 patients), and are gatekeepers to secondary care ${ }^{14,15}$. It has previously demonstrated that there are differences in between patient lists about medical and social morbidity burden according to the Madrid town district where people live ${ }^{16}$. RPS and MPF work in a deprived district and JG in a wealthy one. MPF is a female GP; RPS and JG are males. Years as principal in the recording post was 2 (MPF), 6 (RPS) and 15 (JG). During one year (1995, from $1^{\text {st }}$ January to $31^{\text {st }}$ December) we recorded all direct encounters (face to face) in which a patient cries. The definition of crying is not about the noise but about the emotion and its physiological main consequence, to tear (at least one rolling tear). The following items of information are obtained about the encounter and the patient who cries: age, sex, prior patient status (new/known -for how long, in years), education level, occupation, family structure, place of encounter (health centre/patient's home), consultation time, and reason/s for encounter and health problem/s-diagnosis (principal and the reason to cry). Reason/s for encounter is/ are the agreed statement of the reason/s why a patient enters the health care system, representing the demand for care by that person'. Data on the registration form were coded by JG (member of the WONCA International Classification Committee) using the International Classification of Primary Care $2^{\text {nd }}$ ed. ${ }^{17}$. The unit of analysis was the encounter.

\section{Results}

Patients cried in 157 encounters out of a total of 18,627 direct encounters (face to face), giving an incidence rate of 8.4 per thousand. Table 1 presents the distribution by doctors. Most patients were known (a median of four years) and their median age was 56 years old. Table 2 summarises the most relevant features of the encounters. Male percentage was $9 \%$ in general, but $16 \%$ for the female GP (MPF). 
Table 1. GPs' characteristics, and of their encounters with weeping patients.

\begin{tabular}{|c|c|c|c|}
\hline GP & $J G$ & MPF & RPS \\
\hline Sex & Male & Female & Male \\
\hline Years in the recording position & 15 & 2 & 6 \\
\hline Working days & 195 & 220 & 225 \\
\hline Total number of encounters & 5472 & 6204 & 6951 \\
\hline Home visit & 383 & 352 & 280 \\
\hline Encounters per week & 140 & 141 & 154 \\
\hline Encounters with weeping patients & 74 & 60 & 23 \\
\hline Incidence rate, per thousand & 13.5 & 9.7 & 3.3 \\
\hline Incidence rate, per working week & 1.9 & 1.4 & 0.5 \\
\hline \multirow{3}{*}{$\begin{array}{l}\text { Three more frequents } \\
\text { reasons for encountera }\end{array}$} & P03 & Z28 & Z12 \\
\hline & P01 & P03 & Z14 \\
\hline & Z22 & $\mathrm{Z} 12$ & Z28 \\
\hline \multirow{3}{*}{$\begin{array}{l}\text { Three more frequents } \\
\text { health problems }\end{array}$} & P76 & K91 & P76 \\
\hline & P74 & P74 & Z14 \\
\hline & Z15 & P76 & Z15 \\
\hline
\end{tabular}

anternational Classification of Primary Care - 2 codes $^{9}$ : K91 Cerebrovascular disease; P01 Feeling anxious/nervous/tense; P03 Feeling depressed; P74 Anxiety disorder/ anxiety state; P76 Depressive disorder; Z12 Relationship problem, partners; Z14 Partner illness problem; Z15 Loss or death of partner; Z22 IIIness problem, parent/ family; Z28 Social handicap.

Reasons for encounter and health problems of weeping patients belong mainly to chapters Z, Social Problems, and P, Psychological, especially when in relationship with the crying behaviour (Table 3). More frequent reasons for encounters were: feeling depressed (12.7\%), social handicap (mainly social isolation/living alone) (6.4\%), relationship problem with partners (5.1\%), feeling anxious (3.2\%), illness problem of parents/family (2.6\%), and partner illness problem (1.9\%). More frequent health problems were: depressive disorder $(23,6 \%)$, anxiety disorder $(8.3 \%)$, cerebrovascular disease (5.1\%), and loss/death of partner (3.8\%). Reasons for crying cover the whole range of problems meet in general practice (Table 4).

19 patients cried more than once a year. A patient cried in her seven encounters with MPF; she suffered a stroke and subsequently developed pathological crying, a neurobehavioral sequel. Three patients cried three times and 15 cried twice.

\section{Discussion}

Crying in general practice is not uncommon. The incidence rate of crying in this study, 8.4 per thousand, is higher than the incidence rate of most acute episodes of illness in general practice in Spain, and elsewhere, as gastrointestinal infection, appendicitis, gastrointestinal haemorrhage, gonorrhoea, gout, streptococcal throat, goitre, pneumococcal pneumonia, sprains
Table 2. Characteristics of encounters with weeping patients (total 157).

\begin{tabular}{|c|c|c|}
\hline \multicolumn{2}{|c|}{ Characteristics of encounters } & $\mathrm{n}(\%)$ \\
\hline \multirow{2}{*}{ Patients } & Known & $135(86)$ \\
\hline & New & $22(14)$ \\
\hline \multirow{2}{*}{ Place of the encounter } & Health centre & $145(92)$ \\
\hline & Patient's home & $12(8)$ \\
\hline \multirow{6}{*}{ Age distribution (years) } & $<=14$ & $1(1)$ \\
\hline & $15-24$ & $7(4)$ \\
\hline & $25-44$ & $34(22)$ \\
\hline & $45-64$ & $51(33)$ \\
\hline & $65-74$ & $43(27)$ \\
\hline & $>=75$ & $21(13)$ \\
\hline \multirow{2}{*}{ Sex } & Female & $143(91)$ \\
\hline & Male & $14(9)$ \\
\hline \multirow{5}{*}{ Marital status } & Married & $77(49)$ \\
\hline & Widower & $41(26)$ \\
\hline & Single & $26(16)$ \\
\hline & Divorced & $12(8)$ \\
\hline & Common law & $1(1)$ \\
\hline \multirow{6}{*}{ Labour situation } & Housewife & $77(49)$ \\
\hline & Employed & $38(24)$ \\
\hline & Pensioner & $19(12)$ \\
\hline & Unemployed & $13(8)$ \\
\hline & Student & $9(6)$ \\
\hline & Other & $1(1)$ \\
\hline \multirow{5}{*}{ Level of education } & Illiterate & $19(12)$ \\
\hline & Basic & $91(58)$ \\
\hline & College & $19(12)$ \\
\hline & University & $25(16)$ \\
\hline & Other & $3(2)$ \\
\hline \multirow{5}{*}{ Family structure } & Nuclear & $83(53)$ \\
\hline & Monoparental & $30(19)$ \\
\hline & Living alone & $20(13)$ \\
\hline & Multigenerational & $11(7)$ \\
\hline & Other & $13(8)$ \\
\hline \multirow{4}{*}{$\begin{array}{l}\text { Consultation time } \\
\text { (minutes) }\end{array}$} & $<5$ & $7(4)$ \\
\hline & $5-9$ & $49(31)$ \\
\hline & $10-14$ & $61(39)$ \\
\hline & $>=15$ & $40(26)$ \\
\hline
\end{tabular}

and strains of ankle and foot, cardiac arrhythmia, etc ${ }^{18-22}$. But we do not found in primary care books a specific chapter or section about the topic and how to deal with a tearful patient in general practice (23-29). When GP trainees are asked about their behaviour in this case, it can be described in five steps: $1 /$ let the patient cry, $2 /$ verbalization of emotions and facilitation to express the problem, $3 /$ mutual understanding and solution finding, 4/ evaluation and maintaining contact and $5 /$ personal experience of great emotional effort ${ }^{13}$.

GPs are expected to counsel and support suffering patients but their training rarely gives them an understanding of 
Table 3. Reasons for encounter and health problems of encounters with weeping patients (total 157) (chapters of the International Classification of Primary Care - 2) $)^{9}$.

\begin{tabular}{|c|c|c|c|c|}
\hline \multirow[t]{2}{*}{ Chapter of ICPC-2 } & \multicolumn{2}{|c|}{$\begin{array}{l}\text { In relationship with } \\
\text { crying }\end{array}$} & \multicolumn{2}{|c|}{ Principal } \\
\hline & $\begin{array}{c}\text { Reason } \\
\mathrm{n}(\%)\end{array}$ & $\begin{array}{c}\text { Problem } \\
\mathrm{n}(\%)\end{array}$ & $\begin{array}{c}\text { Reason } \\
\mathrm{n}(\%)\end{array}$ & $\begin{array}{c}\text { Problem } \\
\mathrm{n}(\%) \\
\end{array}$ \\
\hline General & $5(3.2)$ & 0 & $6(3.8)$ & $2(1.3)$ \\
\hline Blood, immunity & 0 & $1(0.6)$ & $3(1.9)$ & $2(1.3)$ \\
\hline Digestive & $5(3.2)$ & 0 & $13(8.3)$ & $7(4.5)$ \\
\hline Eye & $1(0.6)$ & 0 & $3(1.9)$ & $2(1.3)$ \\
\hline Ear & 0 & 0 & $1(0.6)$ & 0 \\
\hline Circulatory & $5(3.2)$ & $8(5.1)$ & $20(12.7)$ & $20(12.7)$ \\
\hline Musculoskeletal & $5(3.2)$ & $4(2.5)$ & $20(12.7)$ & $12(7.6)$ \\
\hline Neurological & $1(0.6)$ & 0 & $8(5.1)$ & $1(0.6)$ \\
\hline Psychological & $35(22.3)$ & $70(44.6)$ & 29 (18.5) & $58(36.9)$ \\
\hline Respiratory & $3(1.9)$ & $2(1.3)$ & $13(8.3)$ & $12(7.6)$ \\
\hline Skin & $1(0.6)$ & 0 & $6(3.8)$ & $3(1.9)$ \\
\hline Endocrine, metabolic & $1(0.6)$ & $2(1.3)$ & $12(7.6)$ & $13(8.3)$ \\
\hline Urological & $1(0.6)$ & 0 & $5(3.2)$ & $6(3.8)$ \\
\hline Pregnancy, family planning & $4(2.5)$ & $3(1.9)$ & $5(3.2)$ & $3(1.9)$ \\
\hline Female genital & $4(2.5)$ & $5(3.2)$ & $5(3.2)$ & $6(3.8)$ \\
\hline Male genital & 0 & 0 & 0 & 0 \\
\hline Social problems & $86(54.8)$ & $62(39.5)$ & $8(5.1)$ & $10(6.4)$ \\
\hline
\end{tabular}

the complex dynamics of strong feelings, how to pursuit therapeutic actions, as empathic action, and how to cope with their own feelings ${ }^{2-6}$. Dealing with patient's intense emotions is one of the GP's most difficult responsibilities in medical practice ${ }^{13,30}$

There are wide variations in the incidence rates, from 3.3 to 13.5 per thousand (Table 1 ), more than four times, as it is usual in any aspect of medical care ${ }^{31}$; for example, in Spain there are differences of up 40 times in the referral rates between different practices ${ }^{32}$ and also about Ambulatory Care Sensitive Conditions ${ }^{33}$. It is not easy to explain the differences, but RPS (lowest rate) had shorter consultation times, and JG (highest rate) had 15 years of continuity in his position. MPF, being a female, might overcome her shorter period of continuity (only two years) as she had more male patients who cried and have an incidence rate of 9.7 per thousand. This rate might indicate a different female approach to patients' social and psychological problem and/or a "safer" female environment for strong feelings. Women patients were more likely to cry in general practice, a finding in accordance with other research on crying ${ }^{5,13}$, but according to our results men might cry more frequently when attended by a female GP.

Patients can cry in their first encounter (14\% of patients who cried were new patients) and at home (8\%) (Table 2). Encounters were longer than usual, as $65 \%$ lasted ten minutes or more [mean time in Spain is five minutes, and only $13 \%$
Table 4. Reasons for crying, as recorded. A few examples.

1. He has not enough money for his family.

2. He is a terminal patient and is afraid of dying.

3. He is unemployed.

4. Her daughter has become divorced.

5. Her daughter is starting with a mental disease.

6. Her dog has died, and she has no relatives.

7. Her husband has a "liason".

8. Her husband has cancer with hepatic metastasis.

9. Her husband has died.

10. Her husband is an alcoholic.

11. Her kitchen has burnt.

12. Her mother has died.

13. Her two daughter are coming back to live at home because economic problems.

14. His brother has been in a psychiatric hospital.

15. His wife has died.

16. She cannot get pregnant.

17. She cannot live with her husband.

18. She does not like to go to live with her daughter.

19. She is afraid of being pregnant.

20. She is afraid of having cancer.

21. She is an English female, student, has diarrhoea, and feels alone in Madrid.

22. She is depressed.

23. She is ill, Moroccan, and feels alone.

24. She is in the process of being divorced.

25. She is in the waiting list, for cataracts surgery.

26. She is losing memory.

27. She has a congenital deformity and cannot accept it.

28. She has a headache.

29. She has an administrative problem with her sickness leave.

30. She has a tongue cancer.

31. She has been battered by his husband.

32. She has excessive menstruation.

33. She has lost her work.

34. She has three sons drug addict.

35. She want not to explain the reason why.

36. Today is the anniversary of her son' death.

of consultations last ten or more minutes $\left.{ }^{34,35}\right)$. Patients from deprived (MPF, RPS) districts have more social problems as reasons for encounters than patients from the wealthy one (JG) (Table 1). Reasons for encounters and health problems mainly belong to chapter $Z$ and $P$ (Table 3). In general practice, chapter $Z$, social problems, represents only a little percentage of the morbidity, from 1 to $4 \%$ as health problems, according to the country ${ }^{22,36}$; in Spain, $1.0 \%{ }^{37}$; in this study, $6.4 \%$ as health problem, principal (Table 3 ). And chapter $\mathrm{P}$, psychological problems, represents 6 to $10 \%$ as health problems, according to the country ${ }^{36}$ and $7.2 \%$ in Spain $^{37}$; in this study, $37 \%$ as health problem principal (Table 3 ). But it is not a surprise to find an over-representation of social and psychological 
problems in weeping patients. Reasons for crying cover the whole range of human problems, from physical pain to "my dog is dead", from poverty to social isolation, from fear of dying to fear of being pregnant, as expected in general practice (Table 4). In contrast, when asking GP in Croatia to comment about crying patients most have as principal problem malignant disease (38\%), family problems $(22 \%)$, death of someone close (18\%), chronic disease (13\%) and other reasons (being social problem, poverty, 3\%) ${ }^{22}$. Perhaps culture and behaviour in Croatia are different, or the GPs remember the situations in a "biological way" which put the focus on biological diseases as cancer.

Our study has many limitations. Main concern is the generalizability of our findings (external validity). Only three GP and one year' registration cannot give a general picture of the question. But our results fit with what we know about General/Family practice as a discipline and our objective was only "to open the box" and know something about the incidence, and reasons for crying in general practice. Another concern might be the "neutrality" of the recording GP (internal validity). We tried to work as usual, and not to refrain, not to reinforce the crying "behaviour" of our patients, and our impression is that the incidence and reasons were as in a normal year.

There are several remaining important questions that should be addressed in future research, like reasons for variability, influence of patient education and the different incidence rates according to patients' and GP' sex, international variations about the weeping patient and so on. But, no doubt, it is a critical topic in General/Family Practice.

\section{Acknowledgements}

This paper is dedicated to A. López-Miras, Spanish GP, who also started the registration about crying patients but could not finished it because a cardiac arrest and subsequent coma status for almost two years before dying in 1997. We tried to publish this paper but have no enough mood until 2012.

\section{References}

1. Yeo M, Longhurts M. Intimacy in the patient-physician relationship. Can Fam Physician. 1996; 42: 1505-8.

2. Platt FW. Conversation repair: Case studies in doctor-patient communication. Boston: Little, Brown and Co.; 1995.

3. Wilmer HA. The doctor-patient relationship and the issues of pity, sympathy, and empathy. Br J Med Psychology. 1968; 41: 243-8. http:// dx.doi.org/10.1111/j.2044-8341.1968.tb02029.x
4. Krauser PS. Tears. JAMA. 1989; 261: 3612. http://dx.doi.org/10.1001/ jama.1989.03420240126039

5. Wagner RE, Hexel M, Bauer WW, Kropriunigg U. Crying in hospitals: a survey of doctors', nurses', and medical students' experience and attitudes. Med J Aust. 1997; 166: 13-6.

6. Nieuwenhuis-Mark RE, Van Hoek A, Vingerhoets A. Understanding excessive crying in neurologic disorders: nature, pathophysiology, assessment, consequences, and treatment. Cogn Behav Neurol. 2008; 21: 111-23. http://dx.doi.org/10.1097/WNN.0b013e31816be8f8

7. Paparrigopoulos T, Ferentinos P, Kouzoupis A, Koutsis G, Papadimitriou GN. The neuropsychiatry of multiple sclerosis: focus on disorders of mood, affect and behaviour. Int Rev Psychiatry. 2010; 22: 14-21. http:// dx.doi.org/10.3109/09540261003589323

8. Presecki P, Mimica NP. Involuntary emotional expression disorder- new/old disease in psychiatry and neurology. Psychiatr Danub. 2007; 19: 184-8.

9. Robinson RG, Parikh RM, Lipsey JR, Starkstein SE, Price TR. Pathological laughing and crying following stroke: Validation of a measurement scale and a double-blind treatment study. Am J Psychiatry. 1993; 150: 286-93.

10. Grinblat N, Grinblat E, Grinblat J. Uncontrolled crying: characteristics and differences from normative crying. Gerontology. 2004; 50: 322-9. http://dx.doi.org/10.1159/000079131

11. Vingerhoets AJ, Rottenberg J, Cevaal A, Nelson JK. Is there a relationship between depression and crying? A review. Acta Psychiatr Scand. 2007; 115: 340-51. http://dx.doi.org/10.1111/j.16000447.2006.00948.x

12. Nyman K. The weeping patient. Aust Fam Physician. 1991; 20: 444-5.

13. Petricek G, Vric-KeglenicM, Lazic C, Murgic L. How to deal with a crying patient? A study from a primary care setting in Croatia using the "critical incident technique". Eur J Gen Pract. 2011; 17: 153-9. http:// dx.doi.org/10.3109/13814788.2011.576339

14. Gérvas J, Pérez-Fernández MM, Starfield B. Primary care, financing and gatekeeping in Western Europe. Fam Pract. 1994; 11: 307-17. http://dx.doi.org/10.1093/fampra/11.3.307

15. Gérvas J, Pérez Fernández M. Organização da atenção primária em outros países do mundo. In: Gusso G, Lopes JMC, coordenadores. Tratado de Medicina de Familia e Comunidade. Porto Alegre: SBMFC Artmed; 2011. v. 1, p. 42-51.

16. Gómez-Rodríguez E, Moreno-Raymundo $P$, Hernández-Monsalve M, Gérvas J. Socio-economic status, chronic morbidity and health services utilization by families. Fam Pract. 1996; 13: 382-5. http:// dx.doi.org/10.1093/fampra/13.4.382

17. World Organization of National Colleges, Academies - WONCA. International Classification Committee. International Classification of Primary Care. 2nd ed. Oxford: Oxford University Press; 1998.

18. Palomo L, Gérvas J, García-Olmos L. La frecuencia de las enfermedades atendidas y su relación con el mantenimiento de la destreza del médico de familia [The frequency of illness attended and its relationship with the maintenance of the family doctor's skill]. Aten Primaria. 1999; 23: 363-70.

19. Fitjen GH, Blijham GH, Knottnerus JA. Occurrence and clinical significance of overt blood loss per rectum in the general population and in medical practice. Br J Gen Pract. 1994; 44: 320-5.

20. Lamberts $\mathrm{H}$, Brouner HJ, Mohrs J. Reason for encounter and episode of care and process oriented standard output from the transition project. Amsterdam: Department of Family Medicine; 1991. v. 1-2.

21. McCormick A, Fleming D, Charlton J. Morbidity statistics from general practice. Fourth national study 1991-1992. London: HMCO; 1995. 
22. Soler JK, Okkes I, Oskams S, Van Boven K, Zivotic P, Jevtic M, et al. An international comparative family medicine study of the Transition Project data from the Netherlands, Malta and Serbia. Is family medicine an international discipline? Comparing incidence and prevalence rates of reasons for encounter and diagnostic titles of episodes of care across populations. Fam Pract. 2012; 29: 283-98. http://dx.doi.org/10.1093/ fampra/cmr098

23. Taylor RB, David AK, Johnson TA, Melesa-Phillips D, Scheger JE. Family medicine: Principles and practice. 4th ed. New York: Spinger Verlag; 1994.

24. Rakel RE. Textbook of family practice. 5th ed. Philadelphia: WB Saunders; 1995

25. Barker LR, Burton JR, Zieve PD. Principles of ambulatory medicine. 4th ed. Baltimore: Willians and Wilkins; 1995.

26. Noble J, Greene HL, Modest GA, Levison W, Young MJ. Textbook of primary care medicine. 2nd ed. St. Louis: Mosby; 1996.

27. Sloane PD, Slatt LM, Ebell MH, Jacques LB. Essentials of familiy medicine. 4th ed. Baltimore: Lippincott Williams Wilkins; 2002.

28. Sociedad Española de Medicina Familiar y Comunitaria - SEMFYC. Tratado de medicina de familia y comunitaria. Barcelona: SEMFYC; 2007.

29. Gusso G, Lopes JM (organizadores). Tratado de Medicina de Família e Comunidade. Porto Alegre: SBMFC Artmed; 2012.

30. Gérvas J, Pérez Fernández M, Gutierrez Parres B. Consultas sagradas: serenidad en el apresuramiento [Sacred encounters: serenity in haste]. Aten Primaria. 2009; 41: 41-4. http://dx.doi.org/10.1016/j. aprim.2008.05.005

31. Andersen TF, Mooney G, editors. The challenges of medical practice variations. Hampshire: MacMillan Press; 1990.
32. García-Olmos LM, Abraira V, Gérvas J, Otero A, Pérez-Fernández M. Variability in GP's referral rates in Spain. Fam Pract. 1995; 12: 159-62. http://dx.doi.org/10.1093/fampra/12.2.159

33. Gérvas J. Hospitalizaciones evitables en España: el poderoso atractivo del hospital y la debilidad de la atención primaria [Ambulatory Care Sensitive Conditions in Spain: the strong attraction of hospital and the weakness of primary care]. In:Variabilidad en las hospitalizaciones potencialmente evitables relacionadas con las reagudizaciones de enfermedades crónicas. Atlas de Variaciones en la Práctica Médica. 2011; 8(4): 329-30.

34. Hart JT. Innovative consultation time as a common European currency. Eur J Gen Pract. 1995; 1: 34-7. http://dx.doi. org/10.3109/13814789509160753

35. Pastor-Sánchez R, López-Miras A, Pérez-Fernández M, Gérvas J. Continuidad y longitudinalidad en medicina general en cuatro países europeos [Continuity and longitudinality of care in general practice in four European countries]. Rev Esp Salud Pública. 1997; 71: 479-85. http://dx.doi.org/10.1590/S1135-57271997000500006

36. Lamberts H, Wood M, Hofmans-Okkes I, editors. The International Classification of Primary Care in the European Community. Oxford: Oxford University Press; 1993.

37. Forés $M$, Gérvas J, Bonet M, Marcos L, Tomás P, Sagués A, et al. ICPC in Spain. Epidemiological aspects of patient data in Spanish general practice. In: Lamberts H, Wood M, Hofmans-Okkes I, editors. The International Classification of Primary Care in the European Community. Oxford: Oxford University Press; 1993. p. 119-24. 